\title{
Fundamental Analysis and the Prediction of Earnings
}

\author{
Dyna Seng (Corresponding author) \\ Department of Accountancy and Finance \\ School of Business, University of Otago \\ P.O. Box 56, Dunedin 9054, New Zealand
}

Tel: 64-3-479-9072Ｅ-mail: dyna.seng@otago.ac.nz

\author{
Jason R. Hancock \\ Department of Accountancy and Finance \\ School of Business, University of Otago \\ P.O. Box 56, Dunedin 9054, New Zealand \\ Tel: 64-3-479-9972 E-mail: hanja599@student.otago.ac.nz
}

Received: October 26, 2011

doi:10.5539/ijbm.v7n3p32
Accepted: December 9, 2011

Published: February 1, 2012

URL: http://dx.doi.org/10.5539/ijbm.v7n3p32

\begin{abstract}
This paper takes fundamental analysis research beyond the spatial and temporal bounds of previous studies. We investigate how detailed financial statement data enter the decisions of market makers by examining how current changes in the fundamental signals chosen can provide information on subsequent earnings changes. Using global data from 1990 to 2000, we extend the body of research using fundamental signals for prediction of future earnings changes. Contextual factors that may influence this predictive ability are also investigated. Results indicate that the fundamental signals are significant predictors of both short- and long-term future earnings changes. Contextual factors that include prior earnings news, industry membership, macroeconomic conditions and country of incorporation are all demonstrated to influence this relationship. Research results provide evidence to support the use of fundamental analysis.
\end{abstract}

Keywords: Capital markets, Fundamental analysis, Contextual analysis, Earnings prediction, Country effect

\section{Introduction}

Capital markets research on fundamental analysis has become extremely popular in recent years, in part because of mounting evidence in the financial economics literature against the efficient markets hypothesis (Kothari, 2001, p.109). Studies that employ fundamental analysis to forecast earnings and future stock returns (i.e., a test of market efficiency) include Ou and Penman (1989a, b), Holthausen and Larcker (1992), Lev and Thiagarajan (1993) and Abarbanell and Bushee (1997, 1998). Fundamental analysis involves the use of current and past financial statements in conjunction with industry and economic data in order to determine firms' intrinsic value and identify mispriced securities (Kothari, 2001).

The research method proposed by Abarbanell and Bushee (1997) is used in this study. The purpose of this paper is to assess the usefulness of financial statements by investigating whether or not non-earnings accounting numbers contain information to assist analysts or investors. In particular, we examine nine individual fundamental signals' relationship to future earnings. In addition, we test the incremental explanatory power of the set of fundamental signals relative to change in current-year earnings. We also investigate whether the information contained in fundamental signals about future earnings is conditioned upon the state of the economy or industry (contextual factors), following Lev and Thiagarajan (1993) and Abarbanell and Bushee (1997).

In addition to corroborating prior research with fundamental analysis, this research adds to what has previously been conducted in two specific ways. First, the earlier research has been largely based in the United States (US), with only the occasional study performed outside the US. This study employs data for the years 1990-2000 from Standard and Poor's Global Vantage database, which contains a large range of information about companies 
worldwide. There are 33 countries included in the period of this study (note 1). Thus, this study takes a new focus and looks at global data rather than simply US data. Second, we extend investigations with examination of the predictive link between the fundamental signals and future earnings change by introducing a country of incorporation as a new contextual factor in order to look for a possible country effect which has not been investigated in prior research.

\section{Literature Review and Hypotheses Development}

Fundamental analysis research has involved testing the ability of fundamental signals to predict either future earnings or stock returns. In addition, it tests for other contextual factors such as the state of the economy or industry that may affect the prediction of future earnings or stock returns.

\subsection{Fundamental Analysis}

Fundamental analysis involves assessing a firm's equity value based on the analysis of published financial statements and other information without reference to the prices at which a firm's securities trade in the capital markets (Bauman, 1996, p.1). It has been stated that "the task of research is to discover what information projects future earnings and, from a financial statement analysis point of view, what information in the financial statements does this" (Penman, 1992, p.471). Showing the value relevance of these non-earnings accounting numbers also indicates the importance and usefulness of financial statements despite the current earnings number's lack of timeliness.

Several authors (e.g., Ou, 1990; Stober, 1993; Kerstein and Kim, 1995) have examined the information content of individual accounting numbers and looked at their usefulness for predicting future earnings or returns. Ou's (1990) results provide evidence for a "predictive information link" between non-earnings numbers and future earnings changes. They indicate that some non-earnings numbers do contain information useful for predicting future earnings changes that is not contained in either past or current earnings. Ou (1990) also extends her test to include a "valuation link" between the predicted future earnings changes and stock returns during the annual report dissemination period. She finds evidence that this valuation link does exist. The non-earnings accounting numbers are therefore useful for predicting both future earnings and returns. Stober's (1993) results show that receivables do provide incremental information for the prediction of future sales, earnings and profit margins. Kerstein and Kim (1995) study the value relevance of capital expenditures for explaining returns beyond the use of current earnings. Their findings show that changes in the level of capital expenditure were strongly and positively related to excess returns. This exhibits the fact that current capital expenditure has good news for the future performance of a firm and supports the use of capital expenditures for predicting future earnings or returns.

An alternative approach would be to include several variables that have the ability to predict earnings and/or returns, rather than a single variable. Authors such as Lev and Thiagarajan (1993), Abarbanell and Bushee (1997, 1998), Al-Debie and Walker (1999), Dowen (2001) and Skogsvik (2008) have chosen this alternate approach and have included so-called fundamental signals that can be used to predict earnings and/or returns.

Lev and Thiagarajan (1993) (hereafter LT) identify various financial variables that are believed to be useful for valuation purposes. These were found through a guided search of various publications such as the Wall Street Journal, Barron's and Value Line in order to identify fundamental signals actually used by analysts and their focus on future earnings/performance. This would also provide variables that can easily be justified. LT identify 12 fundamental signals that are possibly useful for prediction; these include inventory, accounts receivable, capital expenditure, research and development, gross margin, sales and administrative expenses, provision for doubtful receivables, effective tax, order backlog, labour force, last-in-first-out (LIFO) earnings and audit qualification. These signals are then tested based on their incremental information content, beyond earnings, for predicting stock returns. Their results support the value relevance of these fundamental signals with increased explanatory power (compared with earnings alone) in all but three years of the analysis. Another important facet of the LT study is the conditioned or contextual analysis of the relationship between earnings and fundamental signals and stock returns. They allow for the possibility that the effects of these 12 variables may vary depending on three economic variables, namely, consumers' price index, real gross national product (GNP) and the level of business inventory.

LT 12 fundamental signals also form the basis for research by Abarbanell and Bushee (1997) (hereafter AB). In their specific study relating the fundamental signals to future earnings changes (short term (one year ahead) and long term (five-year growth)), they aim to validate the construction of the signals and hence the economic intuition behind their construction. $\mathrm{AB}$ reduce the number of signals to nine for their research because of the way the other three (provision for doubtful receivables, research and development and order backlog) restricted the 
sample. Their results show the coefficients on the signals behaving for the most part as expected; however, capital expenditure and accounts receivable signals had unexpectedly positive coefficients. This could represent different interpretations or signalling effects to those originally proposed by LT. In general, the analysis provides support for the use of these fundamental signals. Following this paper, Abarbanell and Bushee (1998) extend the research to see if using fundamental analysis can yield abnormal returns. They formed portfolios based on the signals that earned, on average, a 12-month cumulative abnormal return of $13.2 \%$. This was therefore evidence that the signals identified information about future earnings that is related to future returns. The results are consistent with those of other authors finding support for fundamental analysis, with the added value of using variables motivated by economic arguments. Dowen (2001) extends the Abarbanell and Bushee (1997, 1998) research by including new information developed in finance-related literature as additional signals in the form of dividend yield, firm size and book-to-market value of equity ratio. Monetary policy is also identified as a variable that may condition the relationship. This is based on the belief that monetary policy influences equity returns. Similar results were found. Monetary policy relates both to the observed level of the signals and the level of earnings change. However, monetary policy "does not alter the degree to which future earnings are predictable from publicly available information" (Dowen, 2001, p.495). Pierce-Brown (1998) uses five major ratios to predict earnings and finds the direction of future earnings changes was correctly predicted $69 \%$ of the time. Based on these findings, an abnormal return (on average $6 \%$ over the three-year test period) could be earned. She concluded that "it seems that there is more valuable information in a set of accounts than just the bottom line." (Pierce-Brown, 1998, p.99). She also noted fundamental analysis as being a sound basis on which to make an investment decision. A more recent research by Dichev and Tang (2009), which investigate the link between earnings volatility and short- and long-term earnings predictability indicate that low-volatility earnings have much higher persistence across quintile portfolios as compared to high-volatility earnings for the short-term earnings predictability. They also find that the strength of the earnings volatility effect exceeds that of cash flows volatility, the accrual effect from Sloan (1996) and the extreme-earnings mean-reversion effect from Freeman et al. (1982). The results from their long-term earnings predictability indicate that the low-volatility earnings have notably high persistence and during the entire predictive horizon, while the high-volatility earnings show quick reversion to the mean and little reliable predictability. All of this literature supports the view that rather than focusing on the aggregate accounting earnings number, one should make use of the other substantial information in the financial statements.

Most of the research to date is based on either US or UK data, but research is not limited to these countries. Mukherji, Dhatt and Kim (1997) investigate fundamental analysis in the Korean stock market. Various ratios such as book-to-market and debt-equity ratios were found to be positively related to stock returns. Mexico has also been involved in fundamental analysis research. Swanson, Rees and Juarez-Valdes (2003) chose to study Mexico, in particular to look at any effects of inflation on the model. Once again, the fundamental signals used in Swanson et al.'s (2003) study are based on those prepared by LT. Their results again indicate the usefulness of fundamental analysis. Skogsvik (2008) investigates whether Swedish financial statement information can be used to predict changes in the medium-term (3-year) book return on owners' equity (ROE). Independent variables include past (3-year) average ROE and 20 other accounting ratios. The results show that univariate prediction model based on past average ROE correctly predicted $71 \%$ of the observations in a hold-out sample. However, only $63 \%$ of the observations were correctly predicted when the other 20 accounting ratios were included in the prediction models.

The model set up by the previous authors indicates that there is an extremely wide range of variations that can be studied. Fundamental signals are not limited to those used here; others arising from future research may prove to be more appropriate. Our aim in this paper is to replicate parts of AB to test for external validity as our sample consists of US and non-US data.

In regards to the predictive link between fundamental signals and future earnings, the hypothesis is

$\mathrm{H}_{1}$ : The fundamental signals provide additional information content beyond current earnings changes for predicting future earnings changes.

\subsection{Contextual Analysis}

Previous research on the value relevance of earnings and other fundamentals was generally conducted in an unconditioned (non-contextual) mode (LT, p.205). Conditioning the analysis on macroeconomic variables seems to be an important aspect of the research to date. Some outside conditions, such as the state of the economy or industry, may in fact influence the relationship between the fundamental signals, and future earnings or returns and contextual (conditional) analysis acknowledges this possibility. Contextual analyses are also designed to 
overcome the lack of power associated with the cross-sectional approach. Contextual studies do not necessarily attack the problem on an industry-specific basis (Bauman, 1996, p.23).

LT condition the analysis on macroeconomic variables because they believe that it is important to allow for the changing economic environment whereby the signals can be strengthened or weakened as the conditions change. LT choose three economic variables for this purpose: an inflation measure to encompass changing prices, an economic growth measure representing the state of the economy and a business inventory measure representing the level of business activity. The relationship between the fundamental signals and returns was expected to differ when the economy is experiencing differing conditions. Values of the coefficients were significantly different based on this conditioned analysis, leading to a better understanding of how the relationship is affected by various economic circumstances (note 2 ). $\mathrm{AB}$ also conduct a contextual analysis. In addition to the inflation and growth variables (note 3 ), they also consider prior earnings news and industry membership. Prior earnings news is considered important because some signals might be more informative if the business has been experiencing prior growth. Industry membership is also relevant because there should be some observable differences between the industries; for example, inventory would not be expected to be as important for service industries.

While inflation and economic growth are considered important for both studies above, there are many other economic variables that other authors place value on. Dowen (2001), for example, extends AB work by adding a monetary policy variable. He aims to show a monetary policy effect is distinct from either inflation or economic growth and his results support this view. Beneish, Lee and Tarpley (2001) examine the predictability of extreme stock returns using contextual fundamental analysis among growth firms. Their results show that while market-based variables are useful in identifying potential extreme price movements, it is accounting-based fundamental signals that are important in separating losers from winners among the subset of predicted extreme performers. They also find that, among predicted extreme performers, losers are firms which are large, have lower sales growth, lower price momentum, greater declines in gross margin, more negative recent earnings surprises, more positive accruals, and higher capital expenditures. The findings of Beneish et al. (2001) are complementary to a study by Piotroski (2000), which focuses on the set of value firms or high $\mathrm{B} / \mathrm{P}$ (book-to-price ratio) firms. Piotroski (2000) indicates that fundamental accounting signals are useful in separating winners from losers among high B/P firms. Taken together, the findings of Beneish et al. (2001) and Piotroski (2000) show the contrast between growth and value firms. Apergis (1999) directly looks at forecasting share prices based solely on macroeconomic fundamentals. He finds that share prices could be forecast better than a random walk model based on these fundamentals, indicating that they may have explanatory power rather than just a conditioning effect. A literature review by Apergis identifies several possible macroeconomic variables, money supply/monetary policy with interest rates as a proxy, inflation, changes in real production levels (economic growth), exchange rates and oil price shocks. Although some forecasting ability is found, he notes that "it is extremely difficult to adopt a thesis about market inefficiency or not" (Apergis, 1999, p.175). Al-Debie and Walker (1999) replicates and extends the work of LT by using UK data and allowing for both macro-economic state (inflation rate, real GNP growth and unemployment rate) and industry variation in the response parameters of non-earnings signals. Their main results are consistent with those of LT. They have identified three non-earnings signals (Gross Profit, distribution and Administrative Expenses, and Labour force) which appear to be frequently significant. Their findings also show that the adjusted $\mathrm{R}^{2}$ increases from $34.11 \%$ (base model) to $37.59 \%$ with no macro-state or industry variation. When the parameters of the non-earnings signals are allowed to vary with macro-state alone, the adjusted $\mathrm{R}^{2}$ falls to $36.29 \%$ which is inconsistent with LT's findings. In addition, when the parameters of the signals are allowed to vary by industry, the adjusted $\mathrm{R}^{2}$ rises from $34.11 \%$ to $40.01 \%$. Finally a further improvement is achieved by allowing the industry specific response coefficients to vary with macro-state. The adjusted $\mathrm{R}^{2}$ rises to $42.81 \%$.

Factors other than economic ones have also been studied. Ali and Hwang (2000) focus on country-specific factors and the effect they have on the value relevance of accounting variables (earnings and book value of equity) explaining security returns. Five country specifics are considered: bank versus market-oriented financial systems, private sector involvement in standard setting, continental versus British-American model countries, tax rules and expenditure on auditing services. Our current research is based on a global data set and checking for a country effect (i.e., US versus non-US) would appear to be necessary. From these papers, it is obvious that this conditioned analysis is an important part of the research. Conditioning the model helps to eliminate other factors that may be influencing the relationship being examined.

In relation to the contextual factors and their importance in the model the hypothesis is

$\mathrm{H}_{2}$ : Prior earnings news, industry, macroeconomic conditions and country of incorporation have effect on the 
predictive ability of the fundamental signals to predict future earnings changes.

\section{Research Design}

\subsection{Sample}

To conduct this research, a substantial amount of financial and some non-financial items are required for each company over a specified event window. These data are almost entirely obtained from Standard and Poor's Global Vantage database. Contained in this database is a large range of information about companies worldwide (in comparison to the US version COMPUSTAT). Data are required for the years 1990-2000 inclusive to calculate the fundamental signals for 1993-1999 for the short-term analysis and 1993-1995 for the long-term analysis. There are 33 countries included in the period of this study (note 1). In addition to this accounting-based data, the research also required macroeconomic information for each of the countries involved, which, where available, is from EconData's dx database. For the second stage of the research, looking at the contextual factors and their impact, additional information is required. Prior earnings news is available from the previously mentioned sources, but industry membership and economic variables require more information. Industry membership comes from Global Vantage and does not restrict the sample any further. Inflation and gross domestic product (GDP) information does result in further sample size restrictions, with the information not being available for several of the countries included. Country of incorporation is also included as a contextual factor.

\subsection{Measurement of the Variable}

$\mathrm{LT}$ and $\mathrm{AB}$ provide the basis for the tests undertaken in this research. Independent variables consist of nine fundamental signals and a current change in earnings per share (CHGEPS). Each of the fundamental signals has been designed by LT so that the expected relationship with future earnings changes will be negative. Hence, a positive value for any of these signals is bad news for future earnings. Table 1 details the signals included in regression analyses and a brief outline of the expected relationship to expected changes in earnings. The construction of the dependent variables is shown at the bottom of the same table.

\section{Insert Table 1 here}

In order for the research to be conducted, each of the companies needed to have supplied the information necessary to construct each of the nine fundamental signals and the earnings related variables (see Table 1). This requirement meant that a substantial portion of the companies included in the Global Vantage database could not be included in the current research. For the short-term and long-term models, this lack of information restricted the sample to approximately 1000 and 800 companies, respectively.

\subsection{Statistical Tests}

To test hypothesis one, regressions are run for future earnings changes on the current year's earnings change and fundamental signals. That is, cross-sectional regressions are run for each year of the sample and mean coefficients calculated for the overall sample. The regression model is as follows:

$$
\Delta \text { EPS }_{t+\tau, i}=\alpha+\beta_{0} \text { CHGEPS }_{i}+\sum_{j=1}^{9} \beta_{i j} \text { Signals }_{i j}+\mu_{i}
$$

where

- $\quad \Delta \mathrm{EPS}_{t+\tau, i}$ : change in earnings per share (EPS). This can be either the change in one-year-ahead EPS (CEPS1) or the imputed annual growth rate in earnings over five years subsequent to year $t$ (CEPSL).

- $\quad$ CHGEPS: current change in EPS between year $t-1$ and $t$.

- Signals: fundamental signals defined at Table 1.

- $\quad \mu$ : error term.

The regression is run for each year of the sample period (1993-1999) for the short-term future earnings changes with CEPS1 (one-year ahead change in EPS) as the dependent variable. The regression is run again for the sample period 1993-1995 for the long-term growth in earnings with CEPSL (five-year geometric mean in earnings) as the dependent variable.

In order to directly test the hypothesis of whether or not the fundamental signals provide additional information beyond CHGEPS, we will compare the overall explanatory power (adjusted $\mathrm{R}^{2}$ ) of the full model (CHGEPS plus fundamental signals) with that of the reduced model (CHGEPS only). Based on the adjusted $\mathrm{R}^{2}$ values, evidence 
will be obtained to either support or reject the hypothesis. The expectation is that there should be an improvement in the adjusted $\mathrm{R}^{2}$ values in the full model with the fundamental signals helping to explain/predict future earnings changes. This improvement in explanatory power is tested using an F-statistic.

In order to test the second hypothesis, the sample must be split into the different groups for the contextual factors. For example, a high inflation sample and a low inflation sample. Splitting the sample requires that each company be categorised into the different groups: good versus bad prior earnings news, a broad industry classification (broad enough so as not to have too small a sample), high versus low inflation and high versus low GDP. The regression analysis will then be completed as before. An observable difference implies that the contextual factors do have a role in the fundamental analysis conducted here and that they should be considered in future fundamental analysis. An additional factor investigated is the country of incorporation of the companies included in the sample. This involves splitting the sample into those companies incorporated in the US and those incorporated elsewhere. Because of the difficulties associated with the five-year earnings growth (dependent variable had a bimodal distribution), we consider only the one-year-ahead earnings change in relation to the contextual factors.

\section{Results}

\subsection{Usefulness of Fundamental Signals in Predicting Future Earnings}

\subsubsection{Testing the individual fundamental signal's relations to future earnings}

In order to test this relationship, a separate analysis is conducted for both the short-term earnings changes (CEPS1) and long-term earnings growth (CEPSL). The regression was run for each year of the sample period with CEPS1 (one-year-ahead change in EPS) as the dependent variable. Table 2 reports the means of fundamental signal coefficients (row 1 ) from the yearly regressions, their significance and the number of positive (row 2) and negative (row 3 ) yearly coefficients with the number of significant yearly coefficients in parentheses. Calculating the mean coefficient across the years and testing the significance of this value enables a comparison with the results achieved by AB. Their procedure of calculating across-year means is the same as has been done by LT and suggested by Bernard (1987) to avoid problems of cross-sectional dependence in the residuals.

\section{Insert Table 2 here}

Table 2 (rows 2 and 3) shows that gross margin, capital expenditure and effective tax rate were consistently significant (current change in EPS (CHGEPS) was also significant in each year, as would be expected). Of these signals that appeared to be consistently significant, effective tax rate also had the anticipated sign (i.e., negative) in six of the seven years, while gross margin was only negative in four of the seven years, only three of which were significant. Capital expenditure, however, was significantly positive in each of the years. The CHGEPS was also significantly negative each year. The results in Table 2 also show that inventory, effective tax rate and labour force are significant in the anticipated direction (i.e., negative), while capital expenditure and earnings quality are significant but not in the expected direction. $\mathrm{AB}$ also find these signals (inventory, effective tax rate and labour force) to exhibit a significant negative relation to future earnings changes with the addition of gross margin and earnings quality. LT extend this to predicting excess stock returns and also find a significant negative relation.

The capital expenditure signal is unexpectedly positive here, as it is for AB. Looking back, the construction of this signal was $\Delta$ industry capital expenditure $-\Delta$ firm capital expenditure. This result implies that a firm exceeding industry capital expenditure is actually bad news for future earnings. The original construction of this signal is therefore questioned by the results. A possible explanation for this is that firms that had been performing poorly were attempting to catch up with other firms in their industry, so that capital expenditure greater than the industry average would be bad news for future earnings. Earnings quality was also unexpectedly positively related to future earnings. This contrasts with the previous findings and means that, rather than the first-in-first-out (FIFO) inventory method being bad news for future earnings, it is actually good news. The reasoning for the original construction was that, with rising prices, last-in-first-out (LIFO) would result in a better estimation of economic earnings.

This reasoning would appear sound, so this questions the results obtained here. There may be some unidentified factor causing this unexpected result. Gross margin also needs to be considered. This signal was significant in six of the seven years, but three were positive and three negative. Overall, this meant that no effect showed up in the mean coefficients and no decisive result can be reached. CHGEPS was significantly negative every year, which is also consistent with $\mathrm{AB}$. This obviously suggests some temporal association for earnings, as future earnings changes depend on current earnings changes. A negative coefficient also indicates that a current increase in 
earnings is bad news for future earnings, perhaps reflecting some sort of reversal. Generally, the short-term earnings changes results support the view that the fundamental signals are useful for predicting future earnings changes.

The regression models tested on the five-year earnings growth were more complex. On observing the actual data for this dependent variable, it was apparent that the variable had a bimodal distribution. In each of the years, the split in the two sections was at -1 . The five-year earnings growth was calculated as using the geometric mean:

$$
\text { CEPSL }=\left(\sqrt[5]{\frac{\text { Ending Value of EPS }}{\text { Beginning Value of EPS }}}\right)-1
$$

This indicates that the fifth root must be negative in the lower section and positive in the upper section. For the lower section, then, the company must be experiencing negative EPS either currently or in the future to make the fifth root negative. Based on this fact, it appears that there are obviously two sections to consider, and the fundamental signals might have a different relationship to future earnings in each of these distinct sections or a different reasoning behind the fundamental signals. To allow for this, the sample for each year has been split into the upper and lower sections around the point -1 . The sample size in each section is still adequate for regression analysis, and the extreme non-normality and autocorrelation exhibited when using the combined sample are significantly improved.

The results for the five-year earnings growth are reported in Table 2, where the mean coefficients for the lower section (mean growth less than -1 ) are provided in row 4 . The gross margin and selling and administrative expenses are shown to be significant and have the expected relationship with long-term earnings growth. CHGEPS remains significantly negative in this lower section of long-term earnings growth, which is consistent with the results in the short-term earnings change. The mean coefficients for the upper section (mean growth greater than -1) are reported at row 7 of Table 2. The selling and administrative expenses, capital expenditure and effective tax rate are negatively significant in the expected direction, while earnings quality exhibits a significant relationship with the other direction. Comparing these coefficients with those calculated in the lower section, there is obviously a difference in the two sections. Selling and administrative expense are the only coefficients significant in both sections. This supports the decision to split the sample and suggests that different fundamental signals are important, depending on the company's situation. While CHGEPS remains negative, it no longer appears significant in this upper section of long-term earnings growth. The results for the regression on long-term growth in earnings were less conclusive than the short-term, with the bimodal distribution of the dependent variable complicating matters. Overall, fundamental analysis would then appear to be a valuable tool in the prediction of future earnings changes. This result holds for predicting both short- and long-term changes in earnings.

4.1.2 Testing the incremental explanatory power of fundamental signals beyond that of current earnings

Explanatory power appears to be higher in the full model when fundamental signals are included in the model in addition to CHGEPS, than in the reduced model when only CHGEPS is included as an independent variable in the model. As shown in Table 3, the calculated $F$-statistic is statistically significant in each of the years in the sample, suggesting that the addition of fundamental signals does provide incremental explanatory power relative to CHGEPS. The average adjusted $\mathrm{R}^{2}$ of the regression of the full model is approximately .087 , compared with an average adjusted $\mathrm{R}^{2}$ of .056 for the regression of the reduced model in predicting one-year-ahead earnings change.

\section{Insert Table 3 here}

As an additional aspect of this study, an index was created in order to "set a sense of the ex ante predictive power of the signals" (AB, p.7). The index was constructed by assigning a value of one (zero) to signals that were positive (negative) and summing the values for each observation. This index was constructed in the same way as $\mathrm{AB}$, which was similar to that used by LT.

Based on this index, high (low) values are assumed to be bad (good) news for future earnings. The index and CHGEPS were then regressed against future earnings change. The results from the regression, including the index, are shown in Table 4.

\section{Insert Table 4 here}

Again, CHGEPS was significantly negative each year. Coefficients of the index appear to be reliably negative for the one-year-ahead earnings change. The adjusted $\mathrm{R}^{2}$ is higher (in only three of the seven years) in the full model when the index is included in the model in addition to CHGEPS, than in the reduced model when only 
CHGEPS is included as an independent variable in the model. The average adjusted $\mathrm{R}^{2}$ value is approximately .061, compared with an average adjusted $\mathrm{R}^{2}$ of .056 for the regression of the reduced model in predicting one-year-ahead earnings change. Hence, the construction of an index to investigate predictive power of the signals was not clear-cut, as the explanatory power was not greatly increased. AB also find a lack of significantly greater explanatory power in their research, with an average adjusted $\mathrm{R}^{2}$ of .075 for the regression of the full model in predicting one-year-ahead earnings change. An explanation for this result was the equal weighting placed on each of the fundamental signals, which would not appear accurate, as results highlight the importance of some variables over others in predicting future earnings change.

Comparing the adjusted $\mathrm{R}^{2}$ in the full and reduced models for the five-year earnings growth again shows an improvement when the fundamental signals are included in the regression. The improvement in explanatory power was tested using an $F$-test based on yearly regressions as was done for the short-term prediction of one-year-ahead earnings changes. As can be seen in Table 5, the increase in explanatory power was only significant in 1993 for the lower section and 1994 and 1995 for the upper section. The others appear to increase explanatory power but not significantly. These results, while not being overly conclusive, do suggest that the model including the fundamental signals is at least as good as the reduced model in terms of explanatory power.

\section{Insert Table 5 here}

\subsection{Future Earnings Performance and Contextual Analysis}

The investigation into the explanatory power of contextual variables forms the second part of this paper. The results are summarised in Table 6. Evidence in the previous section supports the view that the fundamental signals provide additional information for predicting future changes in earnings. Whilst providing support for this prediction, the difficulties (dependent variable had a bimodal distribution) associated with the long-term prediction (i.e., five-year earnings growth) have led us to consider only the short-term prediction (i.e., one-year-ahead earnings change) in relation to the contextual factors. Here the three contextual factors (prior earnings news, industry and macroeconomic) are considered individually and then followed by the analysis based on country of incorporation.

\section{Insert Table 6 here}

\subsubsection{Firm-specific earnings news context}

To test whether prior earnings news influences the relationship between the fundamental signals and future earnings changes, the sample is split into two groups: those companies with good prior earnings news (i.e., increase in EPS) and those with bad prior earnings news (i.e., decrease in EPS). The data over the seven years in the entire sample were combined and then segregated into the two groups. This is the same approach $\mathrm{AB}$ used for testing this contextual factor. Coefficients obtained from the regression on each group were then compared.

Looking at the results in Table 6, there is a difference in both significance of the coefficients and overall explanatory power. The model performed much better in the bad-news case, with explanatory power of approximately .302, but only about .009 in the good-news case. The significance of the fundamental signals also varied with inventory, accounts receivable, selling and administrative expenses, effective tax rate and labour force all significantly negative and capital expenditure significantly positive in the bad-news sample. The only significant fundamental signal in the good-news sample was labour force. When comparing this with $\mathrm{AB}$, the results are slightly different. They found gross margin and selling and administrative expenses to be informative in the bad-news sample, but gross margin was insignificant in the current results. These results clearly show a major difference in the two samples, with some of the signals only being significant in the bad-news group. With such differences apparent, the introduction of this analysis is shown to be important in order to predict future earnings changes.

\subsubsection{Industry context}

For the contextual factor, industry, the sample was split into four broad categories of industry: manufacturing, primary product, service and wholesale/retail. This was based on industry codes provided for each company in the Global Vantage database. A broad classification such as this brings in some industry differences whilst maintaining enough data in each classification.

Observation of the coefficients in Table 6 highlights several differences between the industries. Firstly, the fundamental signals seemed to have a much greater explanatory power for the service industry, with an adjusted $\mathrm{R}^{2}$ value of .285; whereas for the other industries, it was less than .099. Secondly, none of the fundamental signals were consistently significant across the four categories. Thirdly, inventory shows up as significant in two of the industry groups, manufacturing and primary products, as would be expected with the importance they 
place on inventory. This result is also consistent with AB. However, it was surprisingly not significant in the wholesale/retail industry when it is expected to be, although this could be explained by a more or less constant level of inventory in this industry. Lastly, other variables exhibiting significance in several industries are capital expenditure in all but service industries, suggesting less dependence on capital expenditure; accounts receivable is significant in all but manufacturing industries; and effective tax rate in all but wholesale/retail industries. Gross margin was the only signal not significant at all in these models. Again, CHGEPS is significantly negative across the range of industries. Conditioning the analysis on industry allows for "some basic industry differences that may translate into differential informativeness of some of the fundamental signals" (AB, p.19). The results here support this statement.

Another point of interest is the fact that the service industry appears to have much greater explanatory power, and yet it only has three fundamental signals that are significant plus current change in earnings. The other industries all have more fundamental signals appearing significant but have less explanatory power overall. These observable differences suggest that the industry the company is associated with may influence which signals are significant for predicting future earnings and in which direction this relationship lies.

\subsubsection{Macroeconomic context}

The two macroeconomic factors, economic growth represented by a change in GDP and inflation are considered separately here. Each factor is classed as either being high or low. The entire sample was again combined and then sectioned into the high- and low-GDP-growth partitions. This ensures sufficient data in each of the partitions. The GDP data from the dx database allowed each year (for each country) to simply be classed as having either a high or low change in GDP in comparison with the other years in the sample.

As can be seen in Table 6, there is a small difference between the two categories. Inventory, capital expenditure, effective tax rate and labour force are significant in the same direction in each category (as well as CHGEPS), but for low-GDP partition, selling and administrative expenses, earnings quality and audit qualification are also significant. This translates into a slightly improved adjusted $\mathrm{R}^{2}$ value of .084 compared with .059 in the high-GDP partition. Thus, the low-GDP-growth partition appeared to explain more of the variation in future earnings changes than did the high-GDP-growth partition. The signs of the coefficients are basically the same as discussed previously, with the exception of audit qualification, which changed to positive. This is a major concern and obviously does not adequately represent the data because a qualified audit report should not be good news for future earnings regardless of the level of GDP changes. This matter aside, the evidence does suggest that economic growth in the economy influences the link between the fundamental signals and future earnings changes.

In order to test the effects of inflation experienced in the economy, the sample was dealt with in the same way as for the GDP partition above. The results in Table 6 show some distinction between the two partitions. Inventory, capital expenditure, effective tax rate and labour force are significant in the same direction in the two partitions, as is CHGEPS. Accounts receivable and gross margin are also significant in the low-inflation partition, and both are surprisingly positive, suggesting that, in times of low inflation, these signals are good news for future earnings. When the economy is experiencing low inflation, companies would not be so desperate to collect their accounts receivable as in high inflation, as the money loses its value less rapidly. They would then be able to support greater accounts receivable levels. In the high partition, selling and administrative expenses are significantly negative and both earnings quality and audit qualification are positive. Again, the problem of a positive value for audit qualification arises and draws concern. This suggests that there may be some problems in the analysis here involving the macroeconomic factors. Overall, these factors do have some influence on the usefulness of the fundamental signals. This is in direct contrast to the work of $\mathrm{AB}$, who find that macroeconomic data had very little effect on the usefulness of the fundamental signals for predicting future earnings change. They also find opposite results such as accounts receivable and gross margin were only significant in the high-inflation section, as opposed to the low-inflation section as found here.

\subsubsection{Country context}

An additional aspect of the current study that has not been investigated before is looking for a possible country effect. In this paper, we extend investigations with examination of the predictive link between the fundamental signals and future earnings change by introducing a country of incorporation as a new contextual factor in order to look for a possible country effect. For this factor, the sample was split into US companies and non-US companies. Again, the entire sample rather than a year-by-year approach was used to ensure sufficient data in each of the two categories. Non-US companies rather than each individual country were used for the same reason. From the entire sample, $84 \%$ of companies were incorporated in the US. 
Results in Table 6 show a slightly better level of explanatory power for the US companies (adjusted $\mathrm{R}^{2}$ value of .072 for the US companies compared with .044 for non-US companies). Inventory, capital expenditure and effective tax rate are significant in the same direction in each category. This suggests that these signals are not influenced by these differing contextual factors. For the US companies, gross margin and earnings quality are significant and unexpectedly positive. The other significant signals are of the expected signs. The predictive link between the fundamental signals and future earnings change is shown to be influenced by the country in which the company is incorporated.

\section{Conclusions}

Fundamental signals were believed to be useful for predicting future earnings changes. The results showed that, in both the short and long term, the full model, including both the fundamental signals and current change in earnings (CHGEPS), could explain more of the variation in future earnings changes than the model including the CHGEPS alone. Accordingly, the fundamental signals do provide additional information beyond that of current earnings changes for explaining future earnings changes. Not all of the fundamental signals were significant, and some were significant in the unexpected direction. This contrasts with LT, who find all of them significant for predicting excess returns. Each of the fundamental signals was designed to have a negative relationship to future earnings changes. The ones that emerged as positive suggest that the original reasoning behind the construction of the signals may be flawed. Specifically, capital expenditure was positive in the short term, although this did reverse in the long term, possibly representing the lagged effect of capital expenditure. Earnings quality was also positive with no apparent explanation available.

Evidence was also found to support the idea that the link between fundamental signals and predicted earnings is influenced by the contextual factors. Prior earnings news and industry had obvious differences between the different partitions of the factors. The macroeconomic factors exhibited some slight differences but were not as conclusive as the previous factors. Country of incorporation also appeared to influence the predictive ability of the fundamental signals. While this influence was not as strongly exhibited as others, there were differences noted between US and non-US companies.

Overall, the results suggest that the information contained in financial statements may actually be more useful than some people choose to believe. If this financial statement information can actually be used to predict future earnings changes and/or returns, we must believe that it is actually useful and relevant. The possibility may also exist for this information to be used in an attempt to earn abnormal returns. There is some relationship between earnings and returns. Earnings predictability would then imply return predictability and thus question the efficient market hypothesis.

\section{References}

Abarbanell, J.S., and Bushee, B.J. (1997). Fundamental Analysis, Future Earnings, and Stock Prices. Journal of Accounting Research, Vol. 35, No.1, 1-24. http://dx.doi.org/10.2307/2491464

Abarbanell, J.S., and Bushee, B.J. (1998). Abnormal Returns to a Fundamental Analysis Strategy. The Accounting Review, Vol. 73, No. 1, 19-45.

Al-Debie, M., and Walker, M. (1999). Fundamental Information Analysis: An Extension and UK Evidence. British Accounting Review, Vol. 31, 261-280. http://dx.doi.org/10.1006/bare.1999.0101

Ali, A., and Hwang, L. (2000). Country-Specific Factors Related to Financial Reporting and the Value Relevance of Accounting Data. Journal of Accounting Research, Vol. 38, No. 1, 1-21. http://dx.doi.org/10.2307/2672920

Apergis, N. (1999). Forecasting Stock Prices from Macroeconomic Fundamentals: Further Evidence from an Error Correction Model. Advances in Quantitative Analysis of Finance and Accounting, Vol. 7, 165-177.

Bauman, M.P. (1996). A Review of Fundamental Analysis Research in Accounting. Journal of Accounting Literature, Vol. 15, 1-33.

Beneish, M., Lee, C.M, \& Tarpley, R.L. (2001). Contextual Fundamental Analysis through the Prediction of Extreme Returns. Review of Accounting Studies, Vol. 6, 165-189. http://dx.doi.org/10.1023/A:1011654624255

Bernard, V.L. (1987). Cross-Sectional Dependence and Problems in Inference in Market-Based Accounting Research. Journal of Accounting Research, Vol. 25, No. 1, 1-48. http://dx.doi.org/10.2307/2491257

Dichev, I.L and Tang, V.W. (2009). Earnings Volatility and Earnings Predictability. Journal of Accounting and Economics, Vol. 47, 160-181. http://dx.doi.org/10.1016/j.jacceco.2008.09.005 
Dowen, R.J. (2001). Fundamental Information and Monetary Policy: The Implications for Earnings and Earnings Forecasts. Journal of Business Finance and Accounting, Vol. 28, No. 3/4, 481-501. http://dx.doi.org/10.1111/1468-5957.00382

Freeman, R.N., Ohlson, J.A., and Penman, S.H. (1982). Book Rate of Return and Prediction of Earnings Changes: An Empirical Investigation. Journal of Accounting and Research, Vol. 20, No. 2, 639-653. http://dx.doi.org/10.2307/2490890

Holthausen, R. W., and Larcker, D. F. (1992). The Prediction of Stock Returns using Financial Statement Information. Journal of Accounting and Economics, Vol.15, 373-412. http://dx.doi.org/10.1016/0165-4101(92)90025-W

Kerstein, J., and Kim, S. (1995). The Incremental Information Content of Capital Expenditures. The Accounting Review, Vol. 70, No. 3, 513-526.

Kothari, S.P. (2001). Capital Market Research in Accounting. Journal of Accounting and Economics, Vol. 31, 105-231. http://dx.doi.org/10.1016/S0165-4101(01)00030-1

Lev, B., and Thiagarajan, S.R. (1993). Fundamental Information Analysis. Journal of Accounting Research, Vol. 31, No. 2, 190-215. http://dx.doi.org/10.2307/2491270

Mukherji, S., Dhatt, M.S., and Kim, Y.H. (1997). A Fundamental Analysis of Korean Stock Returns. Financial Analysts Journal, May/June, 75-80. http://dx.doi.org/10.2469/faj.v53.n3.2086

$\mathrm{Ou}$ J.A. (1990). The Information Content of Nonearnings Accounting Numbers as Earnings Predictors. Journal of Accounting Research, Vol. 28, No. 1, 144-163. http://dx.doi.org/10.2307/2491220

Ou, J.A., and Penman, S.H. (1989a). Financial Statement Analysis and the Prediction of Stock Returns. Journal of Accounting and Economics, Vol. 11, 295-329. http://dx.doi.org/10.1016/0165-4101(89)90017-7

Ou, J.A., and Penman, S.H. (1989b). Accounting Measurement, Price-Earnings Ratio, and the Information Content of Security Prices. Journal of Accounting Research, Vol. 27, Supplement, 111-144. http://dx.doi.org/10.2307/2491068

Penman, S.H. (1992). Return to Fundamentals. Journal of Accounting, Auditing and Finance, Vol. 7, 465-483.

Pierce-Brown, R. (1998). Better Odds than the Lottery. Accountancy-International Edition, March, 98-99.

Piotroski, J. D. (2000). Value Investing: The Use of Historical Financial Statement Information to Separate Winners from Losers. Journal of Accounting Research, Vol. 38, 1-41. http://dx.doi.org/10.2307/2672906

Skogsvik, S. (2008). Financial Statement Information, the Prediction of Book Return on Owners' Equity and Market Efficiency: The Swedish Case. Journal of Business Finance \& Accounting, Vol. 35, Nos. 7 \& 8, 795-817. http://dx.doi.org/10.1111/j.1468-5957.2008.02099.x

Sloan, R. (1996). Do Stock Prices Fully Reflect Information in Accruals and Cash Flows About Future Earnings? The Accounting Review, Vol. 77, No. 2, 289-316.

Stober, T.L. (1993). The Incremental Information Content of Receivables in Predicting Sales, Earnings, and Profit Margins. Journal of Accounting, Auditing and Finance, Vol. 8, 447-473.

Swanson, E.P., Rees, L., and Juarez-Valdes, L.F. (2003). The Contribution of Fundamental Analysis after a Currency Devaluation. The Accounting Review, Vol. 78, No. 3, 875-902. http://dx.doi.org/10.2308/accr.2003.78.3.875

\section{Notes}

Note 1. 33 countries include Bermuda, Brazil, British Virgin Islands, Canada, Cayman Islands, Chile, Colombia, Denmark, Finland, France, Germany, Hungary, Indonesia, Ireland, Israel, Italy, Japan, Korea, Liberia, Netherlands, New Zealand, Norway, Panama, Singapore, South Africa, Sweden, Switzerland, Taiwan, Thailand, Turkey, United Kingdom, United States of America and Venezuela.

Note 2. Inflation and growth had some significantly different results, but business inventory had very little effect on the significance of the fundamental signals.

Note 3. Only the two significant economic factors from Lev and Thiagarajan (1993) study were considered. 
Table 1. Measurement of the Variables

\begin{tabular}{|c|c|c|}
\hline $\begin{array}{l}\text { Panel A: } \\
\text { Definitions of } \\
\text { Fundamental } \\
\text { Signal }\end{array}$ & Measurement & Description \\
\hline Inventory (INV) & $\begin{array}{l}\Delta \text { Inventory }-\Delta \text { Sales where } \\
\Delta(\text { all variables }) \text { represents } \\
\frac{\text { Inventory }_{\mathrm{t}}-E\left(\text { Inventory }_{\mathrm{t}}\right)}{E\left(\text { Inventory }_{\mathrm{t}}\right)} \\
\text { and } E\left(\text { Inventory }_{\mathrm{t}}\right)=\frac{\text { Inventory }_{\mathrm{t}-1}+\text { Inventory }_{\mathrm{t}-2}}{2}\end{array}$ & $\begin{array}{l}\text { Increases in inventory greater than } \\
\text { increases in sales generally give a } \\
\text { negative signal. This is because it } \\
\text { suggests difficulties in generating sales } \\
\text { or possible slow-moving/obsolete } \\
\text { inventory items. }\end{array}$ \\
\hline $\begin{array}{l}\text { Accounts Receivable } \\
\text { (AR) }\end{array}$ & $\Delta$ Accounts Receivable $-\Delta$ Sales & $\begin{array}{l}\text { Increases in receivables not matched } \\
\text { by sales give a negative signal. } \\
\text { Increasing receivables can indicate a } \\
\text { loosening of credit policy to try to } \\
\text { boost sales. With the increased } \\
\text { balance, it will increase the doubtful } \\
\text { debts and hence reduce future earnings } \\
\text { as they are written off. }\end{array}$ \\
\hline Gross Margin (GM) & $\Delta$ Sales - $\Delta$ Gross Margin & $\begin{array}{l}\text { A disproportionate decrease in gross } \\
\text { margin (relative to sales) gives a } \\
\text { negative view regarding performance } \\
\text { of the firm. This is generally } \\
\text { considered to be bad news regarding } \\
\text { earnings persistence. }\end{array}$ \\
\hline $\begin{array}{l}\text { Selling \& } \\
\text { Administrative } \\
\text { Expenses } \\
\text { (SA) }\end{array}$ & $\Delta$ Selling and Administrative Expense $-\Delta$ Sales & $\begin{array}{l}\text { A disproportionate increase is a } \\
\text { negative signal, as selling and } \\
\text { administrative expenses should be } \\
\text { approximately fixed. This may suggest } \\
\text { a lack of cost control or increasing } \\
\text { costs. }\end{array}$ \\
\hline $\begin{array}{l}\text { Capital Expenditure } \\
\text { (CAPX) }\end{array}$ & $\begin{array}{l}\Delta \text { Industry Capital Expenditure - } \Delta \text { Firm Capital } \\
\text { Expenditure }\end{array}$ & $\begin{array}{l}\text { A level of capital expenditure by a } \\
\text { firm less than the industry can give a } \\
\text { negative signal regarding future } \\
\text { growth. This would imply that industry } \\
\text { growth would be better than the firm's } \\
\text { growth, which would obviously be bad } \\
\text { news. }\end{array}$ \\
\hline $\begin{array}{l}\text { Effective Tax Rate } \\
\text { (ETR) }\end{array}$ & $\begin{array}{l}\left(\left(\frac{1}{3} \sum_{\tau=1}^{3} \mathrm{ETR}_{\mathrm{t}-\tau}\right)-\mathrm{ETR}_{\mathrm{t}}\right) \times \Delta \mathrm{EPS}_{\mathrm{t}} \quad \text { where } \\
\mathrm{ETR}_{\mathrm{t}}=\frac{\text { Tax Expense }_{\mathrm{t}}}{\text { Earnings Before Tax }_{\mathrm{t}}(\mathrm{EBT})} \text { and EBT }= \\
\text { Pre-tax Income }+ \text { Amortisation of Intangibles }^{\text {Antion }}\end{array}$ & $\begin{array}{l}\text { An unusual decrease in the effective } \\
\text { tax rate is bad news for earnings } \\
\text { persistence, as it will be considered a } \\
\text { transitory effect that will increase } \\
\text { again hence decreasing future } \\
\text { earnings. }\end{array}$ \\
\hline Labour Force (LF) & $\left(\frac{\text { Sales }_{t-1}}{\text { \#Employees }_{t-1}}-\frac{\text { Sales }_{t}}{\text { \#Employees }_{t}}\right) \div\left(\frac{\text { Sales }_{t-1}}{\text { \#Employees }_{t-1}}\right)$ & $\begin{array}{l}\text { This signal measures changes in the } \\
\text { efficiency of labour and is used to } \\
\text { provide a better assessment of future } \\
\text { earnings. A positive value indicates } \\
\text { decreased efficiency or sales per } \\
\text { worker. }\end{array}$ \\
\hline $\begin{array}{l}\text { Earnings Quality } \\
\text { (QUAL) }\end{array}$ & 0 for LIFO, 1 for FIFO or Other Method 0. & $\begin{array}{l}\text { LIFO is more appropriate in times of } \\
\text { increasing prices, as it will give a more } \\
\text { realistic view of current costs. Use of }\end{array}$ \\
\hline
\end{tabular}




\begin{tabular}{|l|l|l|}
\hline & Measurement & $\begin{array}{l}\text { LIFO is considered a positive signal } \\
\text { and given the value of } 0 .\end{array}$ \\
\hline $\begin{array}{l}\text { Audit Quality } \\
\text { (AUDIT) }\end{array}$ & for Unqualified, 1 for Qualified or Adverse & $\begin{array}{l}\text { A qualified audit report obviously } \\
\text { sends a negative message to the market } \\
\text { and hence is assigned the value of } 1 .\end{array}$ \\
\hline $\begin{array}{l}\text { Panel B: Definitions } \\
\text { of Dependent } \\
\text { Variables }\end{array}$ & \multicolumn{1}{|c|}{ Description } \\
\hline $\begin{array}{l}\text { One-Year-Ahead } \\
\text { Change in Earnings } \\
\text { Per Share (CEPS1) }\end{array}$ & $\left(\right.$ EPS $_{\mathrm{t}+1}-$ EPS $\left._{\mathrm{t}}\right) / P_{t-1}$ & $\begin{array}{l}\text { One-year-ahead change in EPS } \\
\text { represents the change in EPS between } \\
\text { the current year } t \text { and the next year } \\
t+1, \text { deflated by share price at the end } \\
\text { of year } t-1 \text {. }\end{array}$ \\
\hline $\begin{array}{l}\text { Long-Term Growth } \\
\text { in Earnings (CEPSL) }\end{array}$ & $\begin{array}{l}\text { CEPSL }=\text { Geometric Mean Rate of Growth in } \\
\text { Earnings between years } t \text { and } t+5 .\end{array}$ & $\begin{array}{l}\text { Future growth in EPS represents the } \\
\text { growth in EPS over the following five } \\
\text { years. }\end{array}$ \\
\hline
\end{tabular}

Table 2. Regressions of Future Changes in Earnings per Share on Prior Changes in Earnings per Share and Fundamental Signals

(Rows include mean coefficients from yearly regressions and the number of positive and negative yearly coefficients, with the number of significant yearly coefficients in parentheses.)

$$
\Delta \operatorname{EPS}_{t+\tau, i}^{a}=\alpha+\beta_{0} \text { CHGEPS }_{i}^{b}+\sum_{j=1}^{9} \beta_{i j} \text { Signals }_{i j}^{c}+\mu_{i}
$$

\begin{tabular}{|c|c|c|c|c|c|c|c|c|c|c|c|}
\hline \multirow{2}{*}{$\begin{array}{l}\text { Dependent } \\
\text { Variables }\end{array}$} & \multicolumn{11}{|c|}{ Independent Variables } \\
\hline & Intercept & $I N V$ & $A R$ & $G M$ & $S A$ & CAPX & ETR & $L F$ & $Q U A L$ & AUDIT & CHGEPS $^{b}$ \\
\hline CEPSI $^{a}$ & 0.0018 & $-0.0078 * *$ & 0.0033 & 0.0008 & -0.0095 & $0.0091 * *$ & $-0.1563^{* *}$ & $-0.0365^{* *}$ & $0.0081^{* *}$ & 0.0019 & $-0.2083 * *$ \\
\hline Positive & $4(1)$ & $1(0)$ & $1(1)$ & $3(3)$ & $3(0)$ & $7(7)$ & $1(0)$ & $0(0)$ & $7(2)$ & $4(0)$ & $0(0)$ \\
\hline Negative & $3(0)$ & $6(2)$ & $6(1)$ & $4(3)$ & $4(1)$ & $0(0)$ & $6(6)$ & $7(3)$ & $0(0)$ & $3(0)$ & $7(7)$ \\
\hline $\begin{array}{l}\text { CEPSL }^{d} \\
\text { Lower }\end{array}$ & $-2.0650 * *$ & 0.0182 & -0.0350 & $-0.1621 * *$ & $-0.0920 * *$ & 0.0195 & -0.6082 & 0.0714 & -0.0420 & 0.0210 & $-0.3423 * *$ \\
\hline Positive & $0(0)$ & $1(0)$ & $1(0)$ & $1(0)$ & $0(0)$ & $2(1)$ & $1(0)$ & $3(0)$ & $2(0)$ & $3(0)$ & $0(0)$ \\
\hline Negative & $3(3)$ & $2(0)$ & $2(0)$ & $2(0)$ & $3(0)$ & $1(0)$ & $2(2)$ & $0(0)$ & $1(1)$ & $0(0)$ & $3(2)$ \\
\hline $\begin{array}{l}\boldsymbol{C E P S L}^{\boldsymbol{d}} \\
\text { Upper }\end{array}$ & $0.0742^{* *}$ & -0.0140 & 0.0217 & 0.0743 & $-0.1170 * *$ & $-0.0078^{* *}$ & $-0.2981 * *$ & 0.0422 & $0.0428^{* *}$ & 0.0184 & -0.1940 \\
\hline Positive & $3(2)$ & $1(0)$ & $2(0)$ & $2(1)$ & $0(0)$ & $0(0)$ & $0(0)$ & $2(0)$ & $3(2)$ & $2(1)$ & $2(1)$ \\
\hline Negative & $0(0)$ & $2(1)$ & $1(0)$ & $1(0)$ & $3(2)$ & $3(0)$ & $3(1)$ & $1(0)$ & $0(0)$ & $1(0)$ & $1(1)$ \\
\hline
\end{tabular}

${ }^{a}$ CEPS1 is the change in one-year-ahead earnings (EPS in year $\mathrm{t}+1$ less year $\mathrm{t}$ earnings, deflated by share price at the end of year $\mathrm{t}-1$ ).

${ }^{\mathrm{b}}$ CHGEPS is the change in EPS between years $\mathrm{t}-1$ and $\mathrm{t}$, deflated by the share price at the end of year $\mathrm{t}-1$.

${ }^{c}$ Fundamental signals. See Table 1 for their definitions.

${ }^{d}$ CEPSL is the imputed annual growth rate in earnings over the five years subsequent to year $\mathrm{t}$.

** indicates significance at the 0.05 level (one-tailed) based on a $t$-statistic calculated as the ratio of the mean coefficient to a standard error based on the distribution of the individual yearly coefficients. 
Table 3. Tests for Improved Explanatory Power When Fundamental Signals Are Included in the Model (for Short-Term Earning Changes [CEPS1])

Full Model: $\quad \Delta \operatorname{EPS}_{t+\tau, i}^{a}=\alpha+\beta_{0}$ CHGEPS $_{i}^{b}+\sum_{j=1}^{9} \beta_{i j}$ Signals $_{i j}^{c}+\mu_{i}$

Reduced Model: $\quad \Delta \operatorname{EPS}_{t+\tau, i}^{a}=\alpha+\beta_{0} \operatorname{CHGEPS}_{i}^{b}+\mu_{i}$

\begin{tabular}{|l|l|l|l|l|l|l|l|l|}
\hline & $\mathbf{1 9 9 3}$ & $\mathbf{1 9 9 4}$ & $\mathbf{1 9 9 5}$ & $\mathbf{1 9 9 6}$ & $\mathbf{1 9 9 7}$ & $\mathbf{1 9 9 8}$ & $\mathbf{1 9 9 9}$ & Average \\
\hline $\begin{array}{l}\text { Adj. R } \mathbf{R}^{\mathbf{2}} \text { FulI }^{(1)} \\
\begin{array}{l}\text { Adj. R } \\
\text { Reduced }\end{array}\end{array}$ & 0.190 & 0.062 & 0.052 & 0.078 & 0.055 & 0.090 & 0.081 & 0.087 \\
F-statistic & 0.171 & 0.029 & 0.036 & 0.057 & 0.030 & 0.064 & 0.005 & 0.056 \\
\hline
\end{tabular}

${ }^{a}$ CEPS1 is the change in one-year-ahead earnings (EPS in year $\mathrm{t}+1$ less year $\mathrm{t}$ earnings, deflated by share price at the end of year $\mathrm{t}-1$ ).

${ }^{\mathrm{b}}$ CHGEPS is the change in EPS between years $\mathrm{t}-1$ and $\mathrm{t}$, deflated by the share price at the end of year $\mathrm{t}-1$.

${ }^{c}$ Fundamental signals. See Table 1 for their definitions.

(1) Full model includes both CHGEPS and fundamental signals.

(2) Reduced model includes CHGEPS only.

*** indicates coefficient is significant at the .01 level (one-tailed).

Table 4. Regression Coefficients from Regressing the Index and Prior Change in EPS on Future Change in EPS

Full Model: $\quad \Delta \operatorname{EPS}_{t+\tau, i}^{a}=\alpha+\beta_{0} \operatorname{CHGEPS}_{i}^{b}+\sum_{j=1}^{9} \beta_{i j} \operatorname{Index}_{i j}^{c}+\mu_{i}$

Reduced Model: $\quad \Delta \operatorname{EPS}_{t+\tau, i}^{a}=\alpha+\beta_{0}$ CHGEPS $_{i}^{b}+\mu_{i}$

\begin{tabular}{|c|c|c|c|c|c|c|c|c|}
\hline Year & 1993 & 1994 & 1995 & 1996 & 1997 & 1998 & 1999 & Average \\
\hline Intercept & $0.0566 * *$ & $0.0574 * *$ & 0.0080 & $0.0532 * *$ & $0.0251^{*}$ & $0.0320 * *$ & $0.0406^{*}$ & \\
\hline CHGEPS $^{b}$ & $-0.344 * *$ & $-0.209^{* *}$ & $-0.169 * *$ & $-0.180 * *$ & $-0.179 * *$ & $-0.341 * *$ & $-0.168^{* *}$ & \\
\hline INDEX & $-0.0048 * *$ & $-0.0081 * *$ & 0.0005 & $-0.0077 * *$ & $-0.0046^{*}$ & $-0.0040 *$ & -0.0058 & \\
\hline Adj. $\mathbf{R}^{\mathbf{2}}$ Full $^{(1)}$ & 0.146 & 0.052 & 0.028 & 0.035 & 0.027 & 0.117 & 0.019 & 0.061 \\
\hline $\begin{array}{l}\text { Adj. } \mathbf{R}^{2} \\
\text { Reduced }^{(2)}\end{array}$ & 0.171 & 0.029 & 0.036 & 0.057 & 0.030 & 0.064 & 0.005 & 0.056 \\
\hline
\end{tabular}

${ }^{a}$ CEPS1 is the change in one-year-ahead earnings (EPS in year $\mathrm{t}+1$ less year $\mathrm{t}$ earnings, deflated by share price at the end of year $\mathrm{t}-1$ ).

${ }^{\mathrm{b}}$ CHGEPS is the change in EPS between years $\mathrm{t}-1$ and $\mathrm{t}$, deflated by the share price at the end of year $\mathrm{t}-1$.

${ }^{\mathrm{c}}$ Index value for a given firm year observation is calculated by first assigning a value of one (zero) to positive (negative) values of each signal and then summing these assigned values.

(1) Full model includes both CHGEPS and index.

(2) Reduced model includes CHGEPS only.

* and $* *$ indicates coefficient is significant at the .10 and .05 level (one-tailed), respectively. 
Table 5. Tests for Improved Explanatory Power When Fundamental Signals are Included in the Model (for Long-Term Growth in Earning [CEPSL])

Full Model: $\quad \Delta \operatorname{EPS}_{t+\tau, i}^{a}=\alpha+\beta_{0}$ CHGEPS $_{i}^{b}+\sum_{j=1}^{9} \beta_{i j}$ Signals $_{i j}^{c}+\mu_{i}$

Reduced Model: $\quad \Delta$ EPS ${ }_{t+\tau, i}^{a}=\alpha+\beta_{0}$ CHGEPS ${ }_{i}^{b}+\mu_{i}$

\begin{tabular}{|c|c|c|c|c|}
\hline CEPSL $^{a}$ : Lower Section & 1993 & 1994 & 1995 & Average \\
\hline Adj. $\mathbf{R}^{2}$ Full ${ }^{(1)}$ & 0.115 & 0.037 & 0.023 & 0.0583 \\
\hline Adj. $\mathbf{R}^{2}$ Reduced $^{(2)}$ & 0.038 & 0.021 & -0.012 & 0.0157 \\
\hline F-statistic & $3.053 * *$ & 1.358 & 1.484 & \\
\hline \multicolumn{5}{|l|}{ CEPSL $^{a}$ : Upper Section } \\
\hline Adj. $\mathbf{R}^{2}$ Full ${ }^{(1)}$ & 0.007 & 0.015 & 0.131 & 0.0510 \\
\hline Adj. $\mathbf{R}^{2}$ Reduced $^{(2)}$ & -0.002 & 0.003 & 0.007 & 0.0260 \\
\hline F-statistic & 1.568 & $1.782 *$ & $2.876^{* *}$ & \\
\hline
\end{tabular}

${ }^{a}$ CEPSL is the imputed annual growth rate in earnings over the five years subsequent to year $\mathrm{t}$.

${ }^{\mathrm{b}}$ CHGEPS is the change in EPS between years $\mathrm{t}-1$ and $\mathrm{t}$, deflated by the share price at the end of year $\mathrm{t}-1$.

${ }^{c}$ Fundamental signals. See Table 1 for their definitions.

(1) Full model includes both CHGEPS and fundamental signals.

(2) Reduced model includes on CHGEPS only.

* and ** indicates the F-statistic is significant at the .10 and .05 level (one-tailed), respectively.

Table 6. Regressions of Future Changes in Earnings per Share on Prior Changes in EPS and Fundamental Signals by Contextual Factors

(Rows include Mean Coefficients from Yearly Regressions.)

$$
\Delta \text { EPS }{ }_{t+\tau, i}^{a}=\alpha+\beta_{0} \text { CHGEPS } \quad{ }_{i}^{b}+\sum_{j=1}^{9} \beta_{i j} \text { Signals } \quad \underset{i j}{c}+\mu_{i}
$$

\begin{tabular}{|c|c|c|c|c|c|c|c|c|c|c|c|c|}
\hline \multirow{2}{*}{$\begin{array}{l}\text { Dependent } \\
\text { Variable } \\
\left.\text { (CEPS1 }^{\mathrm{a}}\right) \\
\text { Contextual } \\
\text { Factors } \\
\text { Earnings Ncws }\end{array}$} & \multicolumn{12}{|c|}{ Independent Variables } \\
\hline & Intercept & $I N V$ & $A R$ & $G M$ & $S A$ & $C A P X$ & $E T R$ & $L F$ & $Q U A L$ & AUDIT & CHGEPS $^{b}$ & $\begin{array}{c}\text { Adjusted } \\
R^{2}\end{array}$ \\
\hline Bad News & $-0.0233^{* *}$ & $-0.0131 * *$ & $-0.0144 *$ & -0.0160 & $-0.0318^{* *}$ & $0.0062 * *$ & $-0.1340 * *$ & $-0.0247^{*}$ & 0.0081 & 0.0084 & $-0.6680 * *$ & 0.302 \\
\hline Good News & -0.0036 & -0.0056 & 0.0003 & 0.0046 & -0.0120 & 0.0009 & -0.0351 & $-0.0300 * *$ & 0.0026 & -0.0008 & $-0.1100 * *$ & 0.009 \\
\hline \multicolumn{13}{|l|}{ Industry Sectors } \\
\hline Mamufacturing & 0.0039 & $-0.0094 * *$ & 0.0027 & -0.0146 & -0.0089 & $0.0046^{* *}$ & $-0.1010 * *$ & $-0.0229 *$ & $0.0093^{*}$ & $0.0121 * *$ & $-0.188 * *$ & 0.040 \\
\hline Primary & 0.0046 & $-0.0189 * *$ & $0.0277 * *$ & -0.0112 & -0.0099 & $0.0034 * *$ & $-0.1480^{* *}$ & -0.0184 & 0.0014 & -0.0025 & $-0.216^{* *}$ & 0.060 \\
\hline Service & -0.0251 & 0.0035 & $-0.0358^{* *}$ & 0.0408 & $-0.0790^{* * *}$ & 0.0055 & $-0.8460^{* *}$ & -0.0195 & 0.0412 & 0.0108 & $-0.443^{* *}$ & 0.285 \\
\hline Wholesale' Retail & -0.0050 & -0.0034 & $-0.0167 * *$ & -0.0174 & $-0.0407 *$ & $0.0046^{*}$ & -0.0468 & -0.0080 & $0.0184 * *$ & $-0.0195^{* *}$ & $-0.276 * *$ & 0.099 \\
\hline \multicolumn{13}{|l|}{ GDP Growth } \\
\hline High & -0.0016 & $-0.0097 * *$ & -0.0006 & -0.0042 & 0.0044 & $0.0059 * *$ & $-0.185^{* *}$ & $-0.0280 * *$ & 0.0047 & -0.0041 & $-0.1910 * *$ & 0.059 \\
\hline Low & 0.0052 & $-0.0066^{*}$ & 0.0017 & 0.0026 & $-0.0208^{* * *}$ & $0.0053^{* *}$ & $-0.0657 * *$ & $-0.0293 * *$ & $0.0099 * *$ & $0.0087 * *$ & $-0.2630 * *$ & 0.084 \\
\hline \multicolumn{13}{|l|}{ Inflation } \\
\hline \multicolumn{13}{|l|}{ Incorporation } \\
\hline US & 0.0029 & $-0.0078 * *$ & 0.0005 & $0.0122 *$ & 0.0060 & $0.0046^{* *}$ & $-0.1040 * *$ & $-0.0330 * *$ & $0.0085^{* *}$ & 0.0038 & $-0.226 * *$ & 0.072 \\
\hline Non-US & -0.0073 & $-0.0133 * *$ & -0.0003 & -0.0190 & $-0.0372 * *$ & $0.0057 * *$ & $-0.2890 * *$ & 0.0067 & 0.0139 & 0.0092 & $-0.160 * *$ & 0.044 \\
\hline
\end{tabular}

${ }^{a}$ CEPS1 is the change in one-year-ahead earnings (EPS in year $\mathrm{t}+1$ less year $\mathrm{t}$ earnings, deflated by share price at the end of year $\mathrm{t}-1)$.

${ }^{\mathrm{b}}$ CHGEPS is the change in EPS between years $\mathrm{t}-1$ and $\mathrm{t}$, deflated by the share price at the end of year $\mathrm{t}-1$.

${ }^{c}$ Fundamental signals. See Table 1 for their definitions.

$*$ and $* *$ indicates coefficient is significant at the .10 and .05 level (one-tailed), respectively. 